УДК:37.035.41

\title{
АКТУАЛЬНОСТЬ ОБРАЗОВАТЕЛЬНЫХ ТВОРЧЕСКИХ ТРЕНДОВ СРЕДИ ТЕХНОЛОГИЧЕСКИ НЕДОКВАЛИФИЦИРОВАННОЙ МОЛОДЕЖИ
}

\author{
Апухтин Александр Федорович \\ кандидат медицинских наук, доцент \\ ФБГОУ ВО Волгоградский государственный \\ медицинский университет Минздрава РФ
}

Аннотация: Проведен анализ образовательных творческих трендов среди технологически недоквалифицированной молодежи, сформулированы критерии недоквалифицированности на основании анализа результатов данных выборочного анкетированного опроса студентов медицинского университета. Рассмотрены пути решения с учетом идейно-политического законодательного регламента основного закона Конституции ГК РФ, подзаконных актов правительства РФ по внесению изменений в ФЗ-273 «Об образовании в РФ».

Ключевые слова: студенты, образовательные тренды, технологическая недоквалификация, Федеральный закон, Конституция, Постановления Правительства.

\section{RELEVANCE OF EDUCATIONAL AND CREATIVE TRENDS AMONG TECHNOLOGICALLY UNSKILLED YOUTH}

\section{Apukhtin Alexander Fedorovich}

Annotation: The analysis of educational creative trends among technologically underqualified youth is carried out, the criteria of underqualification are formulated based on the analysis of the results of a sample questionnaire survey of medical university students. The ways of solution are considered, taking into account the ideological and political legislative regulations of the Basic Law of the Constitution of the Civil Code of the Russian Federation, by-laws of the Government of the Russian Federation on amendments to Federal Law No. 273 "On Education in the Russian Federation". 
Keywords: students, educational trends, technological underqualification, Federal law, Constitution, Government resolutions.

Руководитель Сбербанка Герман Греф в ходе публичной лекции «Новые технологические тренды и модели эффективного менеджмента» [1] отметил, что будущий специалист без компетенций по работе с большими данными, будет недоквалифицирован. Недостаточно эффективный менеджмент в образовании реализуется в форме массовых несанкционированных выступлений с участием студенческой молодежи. Молодым людям хочется заявить о себе. Однако цивилизованных возможностей организации творческой деятельности, за исключением волонтерства, у молодежи чаще всего нет.

Одна из причин творческой недоквалифицированности в молодежной среде это отсутствие базовых компетенций в сфере патентных прав на результаты её деятельности.

Цель исследования: изучить среди студентов медицинского университета, заинтересованность в приобретении базовых компетенций в вопросах создания объектов патентного права на результаты творческой индивидуализации, оценить \% недоквалификации в вопросах авторских и патентных прав на объекты и средства индивидуализации, обозначить пути её устранения.

Материал и методы. Методом гнездовых выборок проведено анонимное анкетирование 102-х студентов 4-го курса лечебного факультета медицинского университета по 15 вопросам предварительно разработанной анкеты. Анкету с вопросами и ответы на неё сохраняли в облачном сервисе GOOGLE таблиц с последующей обработкой программой SPSS-22 IBM.

Результаты. В структуре ответа на вопрос «должны ли изобретения отвечать общественным интересам, принципам гуманности и морали?» преобладали положительные ответы - 59,8\%, скорее «да»- 22,5\%, всего положительно ответили $82,3 \%$ студентов. Из оставшихся $27,7 \%$ ответы распределись следующим образом. Затруднились ответить-10,8\%, отрицательно ответило - 3,9\%, скорее «Нет» чем «Да» ответили - 3\%.

Целесообразность включения вопросов создания и патентования результатов интеллектуальной деятельности (РИД) в образовательные программы высшего профессионального образования (ВПО) - отметили $42,16 \%$ опрошенных, затруднились ответить $29,4 \%$, отметили нецелесообразность данного положения 28,44\%. 
Обсуждение. 6,9\% опрошенных студентов не считают, что объекты РИД должны отвечать общественным интересам, принципам гуманности и морали. $10,8 \%$ студентов затруднились с ответом. Ещё $28,4 \%$ отметили нецелесообразность междисциплинарного образования по вопросам создания и патентования результатов интеллектуальной деятельности (РИД) в образовательные программы высшего профессионального образования. Из полученных данных сделаны следующие критерии, на которых основаны выводы проведенного исследования.

Сформулированы критерии квалифицированности студентов : знают о защите РИД патентами, проявляют интерес к изобретательской деятельности, занимаются какой-либо изобретательской деятельностью, состоят в одном или 2-х студенческих научных кружках, при этом поддерживают условия необходимости соответствия изобретений общественным интересам, принципа гуманности и морали.

Также сформированы критерии недоквалифиции студентов: не знают о защите РИД патентами, не имеют интереса к изобретательству, не заняты какой-либо творчески изобретательской деятельностью, не посещают студенческих научных кружков, не разделяют требований закона соответствия изобретений общественным интересам, принципа гуманности и морали. 46,1 \% опрошенных студентов 4-го курса медицинского университета относится к недоквалифицированной группе, и имеют потенциальные риски протестной молодежи.

Среди протестной молодежи, по данным средств информации, преобладают старшеклассники и студенты младших курсов ВУЗов. Социологи называют эту категорию «старшие (или взрослые) подростки», которые используют в качестве основных каналов потребления информации - интернет, социальные сети, видеосервисы. Предыдущее поколение в начале 2000-х годов, заходило в интернет анонимно, часто скрывая себя. Настоящее поколение подростков, наоборот, ведёт себя демонстративно. Оно использует экспрессивную рефлексию и публичную коммуникацию, в частности, через флешмобы. По мнению психологов, лишь в поздний подростковый период появляется личностный стержень, который вытесняет «стадное» мировоззрение. В числе острых социальных проблем молодежи стоят вопросы деструктивного поведения и противодействия угрозе терроризма. Существующие образовательные возможности превентивной коррекции экстремистских настроений среди недостаточно 
квалифицированнной молодежи неопимально законодательно регламентированы. С одной стороны Федеральным Законом об образовании, с другой -основным Законом-Конституцией РФ. Согласно Ф3-273 «Об образовании в РФ» ст.47 п.3(1) закона гарантирует педагогическому работнику свободу выражения своего мнения. Статья 48 п.1(4) этого же закона обязывает педагогического работника формировать гражданскую позицию обучаемых. Одновременно п.3.ст.48 Ф3-273 запрещает педагогу «использовать образовательную деятельность для политической агитации, принуждения обучающихся к принятию политических, религиозных или иных убеждений либо отказу от них ...для побуждения обучающихся к действиям, противоречащим Конституции Российской Федерации». При этом в Конституции РФ в п.2., ст.13., указано «...никакая идеология не может устанавливаться в качестве государственной или обязательной».Очевидно, что педагог, которому предоставлены «свобода выражения своего мнения» с обязанностью «формировать гражданскую позицию» у обучаемых без государственной идеологии, одновременно законодательно имеет запрет заниматься «политической агитацией» и принуждать обучаемых «к принятию каких-либо убеждений». Фактически педагог, при формировании менеджмента профессиональных, законодательно обоснованных идейнополитических знаний вынужден действовать на свой страх и риск, балансировать на грани конфликта с неоптимально регламентированной законностью. Так в статье 44 пп.1 основного закона РФ в последней действующей редакции от 14.03.2020 указано: «каждому гражданину гарантируется свобода.... творчества, преподавания. Свобода творчества в пп.1.2. статьи 44 основного закона также формирует надлежащую правовую охрану результатов творческой деятельности». Перспективность и актуальность формирования компетенций сферы интеллектуальной собственности (ИС) в образовании отметил председатель правления Фонда «Сколково» Игорь Дроздов, который в мае 2017 г в совете по вопросам интеллектуальной собственности при Совете Федерации Федерального собрания РФ отметил : «.. В сфере образования, в условиях, когда междисциплинарность достигла невероятного состояния, необходимо, чтобы технологическое и гуманитарное образование переплетались, в том числе в сфере интеллектуальной собственности». При этом необходимо исключать направления интеллектуальной деятельности (РИД), которые: «..не могут быть объектами патентных прав, если они противоречат общественным интересам, 
принципам гуманности и морали» изложенному в пп.4.п.4. ст. 1349 ч.IV ГК РФ [2].Совершенно очевидно, что эффективный менеджмент междисциплинарных трендов профессионально ориентированного образования должен отвечать определению объектов патентных прав основного закона РФ.

По мнению главы Минобрнауки, молодежи всегда свойственно протестовать, а государство должно реагировать и «что-то предложить молодым людям» [3]. В контексте дилеммы «что-то предложить...» при этом «сформировать гражданскую позицию» молодежи и «..избежать принуждения..» может быть эффективным формирование междисциплинарных знаний и квалификаций в вопросах патентных прав [4,5], которые можно интегрировать не только в образование [6], но и национальную экономику и медстрахование [7,8].Формируемые на этом паттерны ментального поведения студентов медиков и молодых врачей, способствуют эффективному менеджменту больших объёмов данных и технологически-новационной безопасности России [9]. Возможности междисциплинарного образования заложены в Ф3-№273 «Об образовании». Гл IV.,ст.34., п.6 данного Ф3 ( 29.12 2012 с изм., и доп., 2016-17гг) гласит: обучающимся предоставлены академические права «освоения наряду с учебными предметами, курсами, дисциплинами (модулями) по осваиваемой образовательной программе любых других учебных предметов, курсов, дисциплин (модулей) преподаваемых в организации, осуществляющей образовательную деятельность, в установленном ею порядке, а также преподаваемых в других организациях, осуществляющих образовательную деятельность, учебных предметов, курсов, дисциплин (модулей), одновременное освоение нескольких основных профессиональных образовательных программ». Определенным шагом в решении данного вопроса является недавно одобренный на заседании комиссии Правительства РФ по законопроектной деятельности проект Федерального Закона «О внесении изменений в статьи 5 и 83 Федерального Закона «Об образовании в Российской Федерации». На конкурсной основе бесплатное второе высшее образование, в ближайшей перспективе станет доступно пока лишь творческим специальностям. По ним можно будет получить второе высшее образование с присвоением квалификации режиссёра театра, кино и телевидения, дирижёра, композитора, литературного работника, а также переводчика художественной литературы. По остальным, не творческим специальностям, бесплатное второе высшее образование доступно лишь в форме надежд и ожиданий. 


\section{Выводы.}

1. 46,1 \% опрошенных студентов 4-го курса лечебного факультета медицинского университета не имеют междисциплинарных компетенций в сфере авторских и патентных прав на результаты интеллектуальной деятельности, являются «недоквалифицированной» молодежью.

2. Социальная значимость недоквалификации студентов медиков в вопросах эффективного образовательного менеджмента очевидна и заслуживает серьезного внимания.

3. Для снижения недоквалификации подготавливаемых кадров среди студенческой молодежи необходима законодательная поддержка бесплатно дополнительных образовательно-творческих трендов не только в сфере художественных, но и гуманитарных профессий.

\section{Список литературы}

1. Греф предрек вымирание медвузов. URL доступ: http://www.univadis.ru/business-news/184/Gref-predrek-vymiraniemedvuzov?utm_source=newsletter+email\&utm_ medium $=$ email\&utm_campaign=medical+updates+-+daily\&utm__ content $=\quad 1481340$ \&utm_term =automated_daily.Дата обрашения -29.06 .2017 .

2. Статья 1349 ч.IV ГК РФ. Некоммерческая интернет версия консультант Плюс.URL доступ: http://www.consultant.ru/cons/cgi/online.cgi?req=doc\&base=LAW\&n=203243\&fld $=134 \& \mathrm{dst}=100746,0 \& \mathrm{rnd}=0.8898710754853745 \# 0$.Дата обращения 10.04.17.

3. Глава Минобрнауки призвала дать протестной молодежи самое хорошее. URL доступ: http://fedpress.ru/news/77/society/1788813 Дата публикации 18-05-2017.

4. Apukhtin A. F. Extracurricular inventive activity of medical students. International Journal of Applied and Fundamental Research.2016. - №5. - C.1 .

5. Апухтин А.Ф., Апухтина М.В. Психологические проблемы и трудности инновационного развития практической медицины регионального уровня. В сборнике: Медицина в XXI веке: тенденции и перспективы. Материалы III Всероссийской научной Интернет-конференции с международным участием. Сервис виртуальных конференций Pax Grid:ИП Синяев Д.Н.2014. - C.12-13.

6. Апухтин А.Ф. Компетентность студентов медиков в сфере интеллектуальной собственности. Международный журнал экспериментального образования. 2016. - №12-1. - С.12-13. 
7. Апухтин А.Ф. Врачебные новации в здравоохранении: в фокусе пути развития в системе ОМС. Журнал NB:Национальная безопасность. 2015. - №8-3., C.54-56.

8. Апухтин А.Ф. Запатентованные медицинские технологии : вопросы применения. Ж.Патенты лицензии. Интеллектуальные права. 2017. №3. - С.73-80.

9. Апухтин А.Ф. Медико-социальные аспекты новаций и изобретательства (на примере региона России). Монография. СанктПетербург. Супериздательство. - 2020. - 282c. DOI: 10.17513/np.439 